\title{
SOME SPECIFIC FEATURES IN THE DEVELOPMENT OF THE DUAL IN SLOVENE AS COMPARED TO OTHER SLAVIC LANGUAGES
}

1. Tesnière's work "Les formes du duel en Slovène" and his "Atlas linguistique pour servir à l'étude du duel en slovène" has remained the basic work to consult in dealing with the category of the dual in Slovene and has been used as well by linguists researching this category in other Slavic languages. Tesnière himself explained the reason for doing his research: the dual greatly interested his teacher A. Meillet and Tesnière wanted to study this category and the way it was disappearing in a modern European language, the choice being very limited (he mentioned certain speakers of Lithuanian, and three Slavic languages: Slovene, Slovincian ${ }^{1}$ and Lower Sorbian; Tesnière 1925a: VIII; all references in this paper are to Tesnière 1925a).

Using the method of linguistic geography as well as historical linguistic evidence, Tesnière made the following conclusions concerning different stages in the demise of the dual in Slovene (424-25):

1. In case forms the locative disappears first, followed by the genitive, dative, instrumental and finally the nominative and accusative.

2. The dual disappears first in the feminine, then in the neuter and finally in the masculine gender.

3. In parts of speech the dual is lost first in the adjective, then in the demonstrative pronoun, the noun, the numeral and the personal pronoun. Tesnière established that the verb has its own special development: it seems that at first the dual in the verb was rapidly disappearing. However, at a certain point the language reacted in the opposite direction so that today the verb is one of the parts of speech where the dual is best preserved (424-25).

Though Tesnière does not mention it in the "conclusion générale" but in the "conclusion sur les pronoms" (316-317), he thought that the personal pronoun had a parallel development to that of the verb. It seems that at an earlier stage of development the dual pronouns showed a tendency to disappear and that later the development of the 
Slovene dual took another direction and the use of the dual in the personal pronouns became rigorous.

The findings of Tesnière regarding the special status of the pronoun and verb indicate that the development of the pronominal and verbal forms is especially interesting and crucial for the Slovene dual. ${ }^{2}$

In my paper I would like to concentrate on these forms and compare what is known about their development to data from other Slavic languages.

2. As stated already by Belić (I), Slavic languages offer very useful material for the study of the dual. It was fairly regularly used in Old Church Slavonic and substantial traces of it can be found in old texts of other Slavic languages. It disappeared, however, in all living Slavic languages except in Slovene and Sorbian, more specifically Lower Sorbian. ${ }^{3}$ In comparison to Sorbian the dual in Slovene has been lost to a greater degree and only parts of it have survived.

These are the supposed dual pronominal and verbal forms in Common Slavic:

$1 \mathrm{sg}$ azŭ jesmĭ 1 du vě jesvě $1 \mathrm{pl}$ my jesmŭ/-mo/-me/-my

$2 \mathrm{sg}$ ty jesi $2 \mathrm{du}$ vy/va jesta $2 \mathrm{pl}$ vy jeste

$3 \mathrm{sg} \mathrm{m}$ onŭ $] \quad 3 \mathrm{du} \mathrm{m}$ ona $\}$ jeste $3 \mathrm{pl} \mathrm{m}$ oni

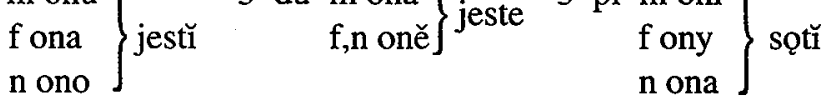

There is some uncertainty regarding the nominative of the 2 du pronoun. In Old Church Slavonic the form $v a$ is attested besides $v y$ (Diehls: 214) and this is usually assumed to be the older form (Lunt: 65, Haburgaev 1974: 209 for Old Church Slavonic; Nahtigal: 60, Ivšić: 218 for Common Slavic). Vy appearing in the place of the $2 \mathrm{du}$ pronoun in several Slavic languages at a very early period (cf. Iordanskij: 16-17, Vážný: 122 ) is usually simply explained as the plural form supplanting the older dual form (Iordanskij: 16-17, Ramovš: 84-85). Decaux proposed seeing in vy an original dual pronoun identical with the plural form. Vaillant (454 ff.) seems to agree with this explanation. $\mathrm{Va}$ is the old accusative of the $2 \mathrm{du}$ pronoun and has in some cases replaced the old nominative $v y$ in order to eliminate the ambiguity of $v y^{4}$

Decaux's and Vaillant's assumption explains the examples in old texts from several Slavic languages where $v y$ appears with a dual verb, e. g.:

Russian Church Slavonic:

tako i vy živěta ... da i vaju bgŭ ublažitǐ (1076; Iordanskij: 16)

2 This fact corresponds to the well-known opinion of Humboldt regarding the prominence of the pronouns in the dual.

3 It seems that in one of the two varieties of Sorbian, namely in Upper Sorbian, the dual has been disappearing recently (Loetsch: 12-13). It is regularly used in both Sorbian standard languages.

4 The du $v y$ goes back to *yu and the pl vy goes back to *yus (Vaillant: 454-455). 


\section{Old Russian:}

vy vedaeta (12th c.; Janin, Zaliznjak: 66)

Sorbian:

wy widzitai a schlyschitai (1670; Loetsch: 59)

\section{Slovene:}

vi sta, ste, sta, Vos duo, duae, duo estis (Bohorič's Grammar 1584, De Verbo, 102) vy nevesta (Dalmatin 1584, Mark 10)

According to Decaux's hypothesis, these examples should not be seen as the start of pluralization (yet Tesnière: 266, Ramovš: 84-85, Iordanskij: 16-17 and also Derganc 1993: 213 saw the demise of the dual in these examples) but correct dual forms in both the pronoun and verb. The identity of the dual pronoun with the plural pronoun was, however, without doubt a strong impulse for pluralization. ${ }^{5}$ In the 1 st person the plural pronoun my could be used with a dual verb:

Russian Church Slavonic

my poslevě; my esvě (15th c.; Iordanskij: 27)

Štokavian:

da sva mi z bratomĭ moimŭ knezomı̆ Stipanomĭ primili te pineze na obiu nau potribu (1476-1470; Belić: 96)

Sorbian:

my njemožachwi (Sus. 39); my njebudzemoj; my chcemoj (Josh. 2)(1728; Loetsch: 60)

Slovene:

my hozheva (Dalmatin 1584, Mark 10)

Mi sva, sve, sva, Nos duo, duae, duo sumus (Bohorič's Grammar, De verbo 102)

Moreover, a plural verb could be used after both $v y$ and $m y$, and so the plural was used in dual contexts. There are of course many such examples in those Slavic languages where the dual eventually disappeared. Yet one can find such examples also in old Slovene and old Sorbian texts:

Slovene:

... my ieimo ... de ne ieimo ... de my lohki ne vmeryemo, sh nikako smertyo ne vmeryete ... bote ieilli ... bodete koker Boguvi, bote veidili ... Jnu kadar sta seslishala ... sta se skrilla ... sta prishla. (1550; Neweklowsky: 3)

5 The semantic causes for the disappearance of the dual in Slavic languages were probably similar to the causes for its demise in the vast majority of other Indoeuropean languages, in which the dual proved to be an unstable category. Here we are speaking about the possible "technical" reasons of its demise.

Decaux's hypothesis also explains why in many Slavic languages the pluralization began precisely in the 2nd person, which seems to be in contradiction with the generalization about the dual pronouns made by Plank (305): If only one person does not differentiate a dual, it will not be the 2nd. 
This example is particularly characteristic: in the story of Adam and Eve the plural occurs in the 1st and 2nd persons, while the dual occurs in the 3rd person.

Loetsch mentions an example in Sorbian where the plural is used in the nominative of the pronoun and in the verb yet the dual is used in the dative of the pronoun in the story about the two sons of Zebedees: my chcemy...my prosić budžemy, žo by ty namaj činil (Mark 10) (1670; Loetsch: 59).

Thus in Slavic languages one of the departure points for the demise of the dual seems to be the weakness of the dual in the nominative of the 1 st and 2 nd person pronouns.

In Slovene and Sorbian, however, this process seems to have been stopped by the creation of new dual personal pronouns (in the nominative; the oblique cases go back to the Common Slavic forms) for the 1 st and 2 nd persons.

3. It seems that an analysis of the 16th c. texts in Slovene (which represent the oldest corpus of Slovene texts where the dual forms can be studied adequately) provides enough data for the general picture. In these texts we find besides the use of $m i$ and $v i$ in a dual context the new forms of the 1 and 2 du pronouns: MIDVA and VIDVA. ${ }^{6}$ These forms were made by reinforcing the $1 \mathrm{pl}$ pronoun $\mathrm{MI}$ and the 2 du pronoun (identical to the $2 \mathrm{pl}$, if Decaux's hypothesis is correct) VI with the numeral "two" - DVA (m) and DVE (f): MIDVA, MIDVE; VIDVA, VIDVE. These new pronouns were marked for gender. In the 16 th $\mathrm{c}$. texts they were used besides the already mentioned forms MI, VI: Midua Ieiua; vidua ne vmerieta. (Trubar 1557: XXII. cap.)

Bohorič speaks about the forms midva and vidva as free variants to $m i$ and $v i$ :

Observatio: In Duali numero, ad Pronomina, maioris evidentiae \& emphaseos causa, adduntur interdum, dva, dve, dva, sic mi dva, nos duo, mi dve, nos duae, mi dvuja, nos duo in neutro genere. Item: vi dva, vos duo, vi dve, vos duae, vi dvuja, vos duo, gen. neutri. Item Onadva, onedve, onadvuja \&c. (De Verbo, 109).

The crucial point is the fact that after $m i$ and $v i$ a dual as well as a plural verb could be used (thus echoing the situation in other Slavic languages, leading to the eventual demise of the dual) while after midva, vidva, as far as I know, only the dual verb could be used. Thus the creation of the new personal pronouns can be seen as a means for rescuing the dual. Though in the 16th $\mathrm{c}$. texts cases can be found where in the $3 \mathrm{rd}$ person plural is used in dual contexts, it seems that these cases are rarer than in the 1st and 2 nd persons. The 3rd person dual masculine pronoun ona goes back directly to the Common Slavic pronoun. In the 16 th $\mathrm{c}$. texts it could be used together with the element $d v a$. Today it is used predominantly in the form onadva. 
Gradually the new personal pronouns prevailed and nowadays midva and vidva (and several other forms, all of them, however, going back to midva and vidva) and the dual verb are used in the majority of Slovene dialects.

Schematically this situation could be presented as follows (only masculine forms are taken into account):

16 th c.:

1. $\mathrm{mi}(\mathrm{pl}) \mathrm{sva}(\mathrm{du}) / \mathrm{mi}(\mathrm{pl}) \mathrm{smo}(\mathrm{pl}) / \operatorname{midva}(\mathrm{du}) \mathrm{sva}(\mathrm{du})$

2. $v i(d u=p l) s t a(d u) / v i(p l=d u) s t e(p l) / v i d v a(d u) s t a(d u)$

3. ona(du) sta(du)/ onadva(du) sta(du)

Contemporary Standard Slovene and the majority of dialects:

1. midva sva

2. vidva sta

3. onadva sta

This difference between the 16th $c$. texts and the current situation obviously induced Tesnière to speak about the development of the dual in verbs and pronouns as being special, namely as showing a tendency to disappear at an early stage and later to become used with great stability.

The new dual personal pronouns had a very transparent structure, their duality being naturally marked by means of the numeral. Their morphological structure was very sound in terms of iconicity (Stolz: $479 \mathrm{ff}$ ).

In Slovene 16th c. texts another creation by analogy can be observed, namely, the verbal endings in all three persons in the present tense is $-a(-v a,-t a,-t a)$, thus corresponding with the masculine dual ending in nouns (brata), adjectives (mlada), participles (bila, pisala) and of course with the numeral $d v a$ and the new pronouns midva, vidva as well as with the old pronoun ona. ${ }^{7}$

These verbal forms seem to have been used with masculine subjects (of course including a masculine and feminine subject linked by a conjunction of the type Adam in Eva) while dual verbs with a feminine subject tended to have the endings -ve, -te, -te (corresponding with some of the feminine nominal endings). This situation had been codified in Bohorič's grammar and examples are also found in the texts:

Mi sekava, ve, va, Nos duo, duae, duo secamus.

Vi sekata, te, ta, Vos duo, ae, o secatis.

Ona, e, a sekata, te, ta. Illi duo, illae duae, illa duo secant. (Bohorič, De Verbo, 108)

7 This unification of the verbal dual endings or at least a tendency towards it can be observed in several Slavic languages, e.g. in Polish (Klemensiewicz et al.: 366) and in Czech (Dostál: 29).

8 A tendency to differentiate gender (masculine and feminine or virile and nonvirile) in dual verbal endings can also be observed in Sorbian, Slovincian and Kašubian (Loetsch: 78-89, Lorentz 1903: 293, Lorentz 1925: 167), i.e. in languages resp. dialects in which the dual had been preserved to some extent. It was also codified in late Church Slavonic grammars (Derganc 1986). 
The verbal endings in $-e$ agreeing with feminine subjects have not proved stable. Today they can be found only in some dialects (Tesnière: $409 \mathrm{ff}$ ). In standard Slovene the verbal endings in $-a$ are used both for masculine and feminine subjects. The skeleton of the new Slovene dual thus seems to be its masculine part, which seems to have been created before the 16th $\mathrm{c}$. by the creation of new dual personal pronouns midva, vidva, onadva and by the unification of the verbal endings in $-a$. These forms together with all agreeing forms (the numeral $d v a$, the masculine nouns, adjectives and participles) ending in $-a$ were clearly marked in opposition to the masculine plural (prevailing ending $-i$ ) and have proved quite stable.

The skeleton of the Slovene dual forms given here in the standard form thus seems to be:

Midva sva mlada. Midva piševa. Midva sva pisala.

Vidva sta mlada. Vidva pišeta. Vidva sta pisala.

Onadva / moja dva brata/ Peter in Pavel/ Adam in Eva sta mlada / pišeta / sta pisala.

In the standard language the use of the dual is required also in cases when the subject is feminine, yet in some dialects in such cases the plural is used (Tesnière: 419ff; Jakopin 1966).

In explaining the history of the new pronominal forms MIDVA and VIDVA Tesnière chose a rather complicated way (259 ff). He assumed that the Common Slavic pronouns $v \check{e}$ and $v a$ had been replaced by $m a$ and $v a$. These two forms were reinforced by the element $d v a$ resulting in madva and vadva. Only after that - the element $d v a$ ensuring the dual meaning - the first dual elements $m a$ and $v a$ could be replaced by the plural elements $m i$ and $v i$, resulting in midva, vidva. The difficulty in this explanation is that the forms $m a, v a$ do not occur in the 16th c. texts nor can they be found in the contemporary dialects. They are attested, however, in some grammars written at the end of the 18th and the beginning of the 19th c. (Pohlin, Gutsman, Kopitar). Some authors thought these forms were probably invented (Toporišič: 108). Ramovš (84-85) and Belic (77ff) did not agree with Tesnière's opinion. They thought the element $d v a$ was attached directly to $m i$ and $v i$.

Yet Tesnière's opinion about the non-linear development of the Slovene pronominal and verbal dual is very important.

4. Similar processes can be observed in Sorbian - the other Slavic language that has preserved the dual. This language has also created new strengthened 1 and $2 \mathrm{du}$ pronouns: ${ }^{9}$

Upper Sorbian: mój, wój

Lower Sorbian: $m e j$, wej

There are some differences in the use of the dual between Slovene and Sorbian. In Slovene, for example, the dual of natural pairs has been systematically replaced by plural forms while in Sorbian the dual in natural pairs is preserved. 
It seems that these forms are made of $m y$ and $v y$ and the ending $-j$ (Loetsch: $61 \mathrm{ff}$ ). The ending $-j$ is a characteristic dual ending in Sorbian and is a Sorbian innovation (Loetsch: 30,32). This ending is also used with verbs in the dual:

Upper Sorbian:

1 du mój smój

2 du wój stej/staj

3 du wonej stej/wonaj staj

(The endings in -aj are used with the genus virile, Trofimovič: 194;202.)

The ending $-j$ is characteristic also of other parts of speech in the dual, e. g. $\mathrm{N} \mathrm{du} \mathrm{m}$ of nouns $d u b a j, \mathrm{~N}$ du of adjectives dobrej/dobraj, of the numeral $\mathrm{m} d w a j$ etc., cf. dual constructions in Sorbian dialects tej dwaj mužaj njesetaj... staj wój wobaj tam botoj (Loetsch: 85). The exact history of the development of these forms is hard to establish (Loetsch: 77ff) yet the result shows clearly the strong extra markedness of many dual forms. They are usually longer than the singular and plural ones, which makes their structure very appropriate in terms of iconicity - the dual being semantically a more complicated category than the plural and the marked member of the opposition (Stolz: 481).

Compared to Sorbian dual forms, only the nominative of the personal pronouns in Slovene has such a clear structure:

MI MI+DVA

pl plural element + dva "two"

MY MÓ+J

pl plural element + specific dual ending

In Slovene the ending $-a$ is not reserved only for the dual. Besides being the old masculine dual ending it is also the $\mathrm{sg} f$ and $\mathrm{pl} \mathrm{n}$ ending, yet the whole dual structure is marked in a stronger way than in the singular and the plural:

$3 \mathrm{sg} \mathrm{m}$ On je mlad.

3 du m Onadva sta $\operatorname{mlad} a$.

$3 \mathrm{pl} \mathrm{m}$ Oni so mladi.

5. One of the points of departure for the weakening of the dual in Slavic languages was the 1 st and 2 nd person personal pronouns in the nominative. This was due to the identity of the dual and plural 2nd person pronoun (if Decaux's hypothesis is correct). In Sorbian and Slovene the language reacted by creating new personal pronouns, which have a very transparent morphological structure signalizing the duality of the forms, and by a stronger markedness of the majority of other dual forms 1) as compared to the plural and singular and 2) as compared to the Common Slavic forms. Thus in order to survive the dual forms had to be strengthened. Both languages have a characteristic dual ending which appears in most parts of speech, even in the verb: the Sorbian ending $-j$ is a Sorbian innovation, while Slovene used for the personal pronoun the numeral $d v a$ and 
for the other forms the old Slavic dual masculine ending $-a$. The dual in both languages therefore cannot be viewed as a simple relic of the dual in Common Slavic.

6. In Slovene the surviving part of the dual seems stable enough and is felt to be pragmatically a useful linguistic device for describing situations in which two persons are involved (cf. Lencek 1982). We cannot forget here the citation of the Slovene author Mencinger that Tesnière used as the motto for his work: "Uganila sta celo, da je slovenski jezik kakor nalašč prijateljski jezik, ker ima posebne oblike za pogovore $\mathrm{v}$ dvojini" (They two have even guessed that Slovene is precisely a language of friendship, since it has special forms for conversation in the dual.)

\section{REFERENCES}

A. BELIĆ, 1932: O dvojini u slovenskim jezicima. Beograd.

A. BOHORIČ, 1584: Arcticae horulae succisivae. Mladinska knjiga \& R. Trofenik. Ljubljana 1970.(=Monumenta litterarum Slovenicarum 7).

J. DALMATIN, 1584: Biblia. R. Trofenik \& Mladinska knjiga. Muenchen 1968 (=Geschichte, Kultur und Geistesleben der Slowenen III.).

E. DECAUX, 1953: Le nominatif duel des pronoms personnels polonais. Revue des études slaves XXX (1-4), 95-97.

A. DERGANC, 1986: O morebitnem vplivu Bohoričeve slovnice na cerkvenoslovansko slovnico Meletija Smotrickega. - 16. stoletje v slovenskem jeziku, književnosti, in kulturi, Obdobja 6, Ljubljana, 319-27.

A. DERGANC, 1988: On the History of Dual in Slovene and Russian, Wiener slawistischer Almanach, Bd. 22, 237-247.

A. DERGANC, 1993: Spremembe nekaterih dvojinskih oblik in zvez v slovenščini in ruščini. Slavistična revija 41, 209-18.

P. DIEHLS, 1932: Altkirchenslavische Grammatik. I. Teil. Heidelberg.

A. DOSTÁL, 1967: Historická mluvnice česká. II. Tvarosloví. 2. část. Časování. Praha.

K. V. GORŠKOVA, G. A. HABURGAEV, 1981: Istoričeskaja grammatika russkogo jazyka. Moskva.

G. A: HABURGAEV, 1974: Staroslavjanskij jazyk. Moskva.

W. HUMBOLDT: Ueber den Dualis. Abhandlungen der historisch-philologischen Klasse der koeniglichen Akademie der Wissenschaften in Berlin aus dem Jahre 1827, Berlin 1830. Russian translation: V. Gumbol'dt, Jazyk i filosofija kul'tury. Moskva 1985.

A. M. IORDANSKIJ, 1960: Istorija dvojstvennogo čisla v russkom jazyke. Vladimir.

S. IVŠIĆ, 1970: Slavenska poredbena gramatika. Zagreb.

F. JAKOPIN, 1966: Slovenska dvojina in jezikovne plasti. Jezik in slovstvo, 4, 98-104.

V. L. JANIN, A. A. ZALIZNJAK, 1986: Novgorodskie gramoty na bereste. Moskva. 
Z. KLEMENSIEWICZ, T. LEHR-SPŁAWIŃSKI, S. URBAŃCZYK, 1965: Gramatyka historyczna języka polskiego. Warszawa.

R. LENCEK, 1982: On Poetic Functions of the Grammatical Category of Dual. South Slavic and Balcan Linguistics. Amsterdam, 193-214.

R. LOETSCH, 1965: Die spezifischen Neuerungen der sorbischen Dualflexion. Bautzen - Budyšin.

F. LORENTZ, 1903: Slovinzische Grammatik. S.-Peterburg.

F. LORENTZ, 1925: Geschichte der pomoranischen (kaschubischen) Sprache. Berlin und Leipzig.

H. LUNT, 1974: Old Church Slavonic Grammar. The Hague-Paris.

R. NAHTIGAL, 1952: Slovanski jeziki. Druga, popravljena in pomnožena izdaja. Ljubljana.

G. NEWEKLOWSKY, 1984: Trubarjev katekizem 1550. Ljubljana.

F. PLANK, 1989: On Humboldt on the Dual. In: R. Corrigan, F. Eckman, M. Noonan (eds), Linguistic Categorization. Amsterdam/Philadelphia.

F. RAMOVŠ, 1952: Morfologija slovenskega jezika. Ljubljana.

Th. STOLZ, 1988: Markierheitshierarchie und Merkmalhaftigkeit in Numerussystemen: Ueber den Dual, Z. Phon. Sprachwiss. Kommunik. forsch. (ZPSK) 41 , 4, 476-87.

A. E. SUPRUN, 1989: Vvedenie v slavjanskuju filologiju. 2-e izd. Minsk.

L. TESNIÈRE, 1925a: Les formes du duel en slovène. Paris.

L. TESNIÈRE, 1925b: Atlas linguistique pour servir à l'étude du duel en slovène. Paris.

J. TOPORIŠIČ, 1983: Pohlinova slovnica, in: XIX. seminar slovenskega jezika, literature in kulture. Ljubljana. 95-128.

K. K. TROFIMOVIČ, 1977: Serbolužickij jazyk. In: Slavjanskie jazyki (Očerki grammatiki zapadnoslavjanskih i južnoslavjanskih jazykov). Moskva.

P. TRUBAR, 1557: Ena dolga predguvor k novemu testamentu. Reprint. CZ. Ljubljana 1986.

A. VAILLANT, 1958: Grammaire comparée des langues slaves. Tome II. Morphologie. Deuxième partie: Flexion pronominale. Lyon, Paris.

V. VÁŽNÝ, 1968: Historická mluvnice česká. II. Tvarosloví. 1. část. Sklonování. 2. vyd. Praha.

Povzetek

NEKAJ ZNAČILNOSTI V RAZVOJU SLOVENSKE DVOJINE GLEDE NA OSTALE SLOVANSKE JEZIKE

Tesnièrjevo delo o dvojini v slovenščini je še danes najizčrpnejši vir za študij te kategorije v slovenščini. Tesnière je povezal metodo lingvistične geografije in študija zgodovinskih virov in postavil določene ugotovitve glede tega, v kakšnem zaporedju izginja dvojina v slovenskih narečjih v posameznih slovničnih kategorijah. Posebno pomembna se zdi njegova ugotovitev, da sta pri šibitvi dvojine glagol in osebni zaimek doživljala poseben razvoj. Tesnière meni, da sta ti dve besedni vrsti nekoč hitro izgubljali dvojinske oblike, da pa se je na neki točki ta 
razvoj ustavil in obrnil v nasprotno smer. Dvojina pri zaimku in glagolu se je tako utrdila, da je današnji značaj dvojine v slovenščini pronominalno-verbalen.

V pričujočem sestavku se postavlja teza, da je ključno vlogo pri tem razvoju igral imenovalnik osebnih zaimkov 1 . in 2. osebe. Na tem mestu je bila - kot se da sklepati po zapisih starejših dob - nasploh ena od šibkih točk dvojine $v$ večini slovanskih jezikov. Razlog za to bi lahko bila od Decauxa postavljena in od Vaillanta sprejeta hipoteza, da sta se $v$ praslovanščini osebni zaimek $v$ imenovalniku dvojine in množine glasila enako - *vy. V slovenščini sta po začetni šibitvi dvojine na tem mestu nastala nova, morfološko zelo transparentna in obstojna imenovalnika dvojinskih osebnih zaimkov MIDVA in VIDVA. To se je očitno zgodilo še pred 16. st. Pred to dobo so se tudi poenotile glagolske končnice (za m. spol) na - $a$. Tako je nastalo zelo dobro markirano (tako nasproti ednini in množini kot tudi nasproti domnevnemu starejšemu stanju) pronominalno-verbalno jedro dvojinskih oblik.

Zdi se, da je bil podoben razvoj dvojinskih oblik v lužiški srbščini. Tudi tu sta nastala nova imenovalnika dvojine za 1. in 2. osebo (mój, wój oz. mej, wej), razvila pa se je tudi za dvojino specifična končnica $-j$, ki zaznamuje precejšen del dvojinskih oblik vključno $z$ glagolskimi.

Zdi se torej, da je $v$ tistih slovanskih jezikih, kjer se je dvojina do neke mere obdržala, prišlo do razvoja novih imenovalnikov osebnih zaimkov 1 . in 2 . osebe ter do morfološko krepkejše markiranosti večjega dela dvojinskih oblik nasproti ostalima številoma in nasproti starejšemu stanju. 